The Journal of Animal \& Plant Sciences, 30(3): 2020, Page: 527-536

ISSN (print): 1018-7081; ISSN (online): 2309-8694

\title{
EFFECT OF VARYING DIETARY LEVELS OF CALCIUM AND PHOSPHORUS ON APPARENT DIGESTIBILITY AND RETENTION OF MACRO AND MICRO-MINERALS IN LACTATING SAHIWAL COWS
}

\author{
M. Z. U. Khan ${ }^{1}$, T. N. Pasha ${ }^{1}$, K. Javed ${ }^{2}$, M. J. Basra ${ }^{3}$ and M. A. Jabbar ${ }^{1}$ \\ ${ }^{1}$ Department of Animal Nutrition, ${ }^{2}$ Department of Livestock Production, University of Veterinary \& Animal Sciences, \\ Lahore; ${ }^{3}$ Livestock Experiment Station, Khizerabad, Sargodha \\ Corresponding author’s email: vetzafar@gmail.com
}

\begin{abstract}
Overfeeding or underfeeding of minerals to the animals may affect health of dairy animals and cost of production. The objective of this study was to investigate the impact of varying dietary levels of $\mathrm{Ca}$ and $\mathrm{P}$ on apparent digestibility and retention of $\mathrm{Ca}, \mathrm{P}, \mathrm{Mg}$ and $\mathrm{Zn}$. For this purpose, 36 second parity Sahiwal cows at peak lactation stage averaging $70 \pm 10$ days in milk (DIM) were offered one of six different treatments of varying levels of $\mathrm{Ca}$ and $\mathrm{P}(\mathrm{NCP}=$ Normal $\mathrm{Ca}$ and $\mathrm{P}$, $\mathrm{HP}=40 \%$ higher $\mathrm{P}, \mathrm{LC}=40 \%$ lower $\mathrm{Ca}, \mathrm{LCHP}=40 \%$ lower $\mathrm{Ca}$ and $40 \%$ higher $\mathrm{P}, \mathrm{HC}=40 \%$ higher $\mathrm{Ca}$, or $\mathrm{HCHP}=$ $40 \%$ higher $\mathrm{Ca}$ and $\mathrm{P}$ ) following a Completely Randomized Design. Dietary Ca and P levels and their ratios did not affect $(\mathrm{P}>0.05)$ daily milk yield. Feeding higher than recommended Ca levels (HC, HCLP, HCHP) resulted in a significant decrease $(\mathrm{P}<0.05)$ in apparent $\mathrm{Ca}$ digestibility and retention and a significant decrease $(\mathrm{P}<0.05)$ in apparent $\mathrm{Zn}$ digestibility. Feeding higher than recommended $\mathrm{P}$ resulted in a significant decrease $(\mathrm{P}<0.05)$ in apparent $\mathrm{P}$ digestibility, irrespective of dietary Ca levels. Dietary P levels did not $(\mathrm{P}>0.05)$ affect apparent Zn digestibility. A decrease $(\mathrm{P}<0.05)$ in apparent digestibility of $\mathrm{Mg}$ was observed in treatment groups $\mathrm{HC}$ and HCHP.
\end{abstract}

Keywords: Calcium, phosphorus, magnesium, varying levels, apparent digestibility.

https://doi.org/10.36899/JAPS.2020.3.0062

Published online March 25, 2020

\section{INTRODUCTION}

For optimal performance of dairy animals, appropriate supply of minerals in diet needs to be considered (Kronqvist, 2011). Diet should be formulated to decrease excretion of valuable nutrients particularly minerals in feces and urine which interferes with underground and surface water quality (Morse et al., 1992; Tamminga, 1992; Underwood and Suttle, 1999) and also contributes in environmental pollution (ChapuisLardy et al., 2004; Knowlton et al., 2005).

Together $\mathrm{Ca}$ and $\mathrm{P}$ make up to $70 \%$ of the total minerals in the body. About $80-85 \%$ of $\mathrm{Ca}, \mathrm{P}$ and $\mathrm{Mg}$ are stored in bones in the form of salts. Bone ash comprises of about $36 \% \mathrm{Ca}$ and $17 \% \mathrm{P}$ and a large part of which is in dynamic state (Harris $\mathrm{Jr}$ et al., 2003). Increase in dietary levels of one mineral may affect digestibility and excretion of others (Khorasani et al., 1997). In the body, $\mathrm{Ca}$ is regulated by homeostatic mechanisms involving 1 , 25-dihydroxyvitamin D, PTH and calcitonin (McDowell, 2003). Source of $\mathrm{P}, \mathrm{P}$ intake, $\mathrm{Ca}$ : $\mathrm{P}$ ratio, gut $\mathrm{pH}$, physiological stage, any parasitic infestation and the inclusion levels of $\mathrm{Ca}, \mathrm{Fe}, \mathrm{Al}, \mathrm{Mn}, \mathrm{K}, \mathrm{Mg}$ and fat are all factors that impact on the absorption of P (Horst, 1986; Harris $\mathrm{Jr}$ et al., 2003). An inverse relationship exists between $\mathrm{P}$ intake and absorption. A high Ca: P ratio may also decrease $\mathrm{P}$ absorption (Schneider et al., 1985) thereby decreasing P availability (Field et al., 1983). The availability of $\mathrm{P}$ depends on the chemical form of the $\mathrm{P}$ and other animal factors such as age, physiological stage of the animal and nutritional status (McDowell and Arthington, 2005).

Excessive intake of Ca may interfere with the absorption and metabolism of other minerals. While $\mathrm{Ca}$ may not have direct effect on $\mathrm{Zn}$ absorption, it can decrease $\mathrm{Zn}$ absorption in the presence of phytate (Oberleas et al., 1996). Other than Zn and Selenium, little information is available on effects of dietary $\mathrm{Ca}$ levels on other trace elements absorption in dairy cows (Harrison and Conrad; 1984; Alfaro et al., 1987). At higher dietary $\mathrm{Ca}$ levels, a negative interaction with $\mathrm{Zn}$ absorption is possible. Alteration in dietary $\mathrm{Ca}$ and $\mathrm{P}$ levels as well as their ratios has been found to have interactions with absorption of other macro and micro-minerals. Dietary $\mathrm{P}$ may have different effects on $\mathrm{Ca}, \mathrm{P}, \mathrm{Mg}$ and $\mathrm{Zn}$ metabolism depending on dietary $\mathrm{Ca}$ levels (Kronqvist, 2011). In certain conditions, high dietary $\mathrm{Ca}$ and $\mathrm{P}$ may interfere with $\mathrm{Zn}$ metabolism (Pond and Wallace, 1986; NRC, 2001). In general, a ratio of $1: 1$ to $2: 1$ is recommended for $\mathrm{Ca}$ and $\mathrm{P}$ in ruminant diet (McDowell, 1992). Some studies have shown that $\mathrm{Ca}: \mathrm{P}$ is not critical unless it is greater than 7:1 or less than 1:1 (Martz et al., 1999). 
The aim of this study was to investigate the effects of dietary levels of $\mathrm{Ca}$ and $\mathrm{P}$ on apparent digestibility and retention of $\mathrm{Ca}, \mathrm{P}, \mathrm{Mg}$ and $\mathrm{Zn}$ in lactating Sahiwal cattle. We hypothesized that an increase in dietary $\mathrm{Ca}$ and $\mathrm{P}$ levels will impact the apparent digestibility and retention of the minerals.

\section{MATERIALS AND METHODS}

This experiment was conducted at Livestock Experiment Station Khizerabad, district Sargodha. Laboratory analyses were undertaken at the Department of Animal Nutrition, UVAS, Lahore. Thirty-six, second parity Sahiwal cows at peak lactation stage averaging $70 \pm 10$ days in milk (DIM) were offered six different dietary treatments (NCP, HP, LC, LCHP, HC and HCHP) with varying levels of $\mathrm{Ca}$ and $\mathrm{P}$ following a completely randomized design. A basal diet was formulated to contain $0.28 \% \mathrm{P}$ on a DM basis. Except for variation in $\mathrm{Ca}$ and $\mathrm{P}$ levels, all diets were formulated according to the recommendations prescribed by NRC (1989) and offered to the animals in the form of a total mixed ration (TMR). The dietary $\mathrm{Ca}$ and $\mathrm{P}$ levels of the experimental diets are presented in Table 1.1., while details of the TMR formula and nutrient profile are presented in Table 1.2 .

Table 1.1. Calcium and phosphorus contents of the experimental rations.

\begin{tabular}{lllc}
\hline Treatment & Ca & P & Ca : P ratio \\
\hline NCP & NRC recommended level & NRC recommended level & $1.2: 1.0$ \\
HP & NRC recommended level & $40 \%$ high than NRC recommendation & $1.2: 1.1$ \\
LC & $40 \%$ lower than NRC recommendations & NRC recommended level & $1.0: 1.0$ \\
LCHP & $40 \%$ lower than NRC recommendations & $40 \%$ higher than NRC recommendations & $1.0: 1.1$ \\
HC & $40 \%$ higher than NRC recommendations & NRC recommended level & $1.4: 1.0$ \\
HCHP & $40 \%$ higher than NRC recommendations & $40 \%$ higher than NRC recommendations & $1.4: 1.1$ \\
\hline
\end{tabular}

Table 1.2. Composition of the basal diet and its associated nutrient profile (DM basis).

\begin{tabular}{|c|c|}
\hline Ingredients & Inclusion level (\%) \\
\hline Wheat straw & 32.80 \\
\hline Maize grains & 20.00 \\
\hline Soybean meal & 16.36 \\
\hline Maize oil cake & 16.00 \\
\hline Rice tips & 6.00 \\
\hline Molasses & 7.00 \\
\hline Vegetable oil & 0.84 \\
\hline Vitamin-mineral premix ${ }^{*}$ & 0.50 \\
\hline Sodium bicarbonate & 0.50 \\
\hline \multicolumn{2}{|l|}{ Chemical composition } \\
\hline Dry matter $(\%)$ & 88.77 \\
\hline Crude protein $(\%)$ & 12.8 \\
\hline Crude fiber $\%$ & 17.11 \\
\hline Metabolizable energy (Mcal/kg) & 2.41 \\
\hline Neutral detergent fiber $(\%)$ & 20.24 \\
\hline Acid detergent fiber $(\%)$ & 32.72 \\
\hline Calcium $(\%)$ & $\begin{array}{c}0.26(40 \% \text { lower than } \\
\text { NRC })\end{array}$ \\
\hline Phosphorus (\%) & 0.28 \\
\hline Magnesium (\%) & 0.22 \\
\hline Sodium (\%) & 0.19 \\
\hline Potassium (\%) & 0.90 \\
\hline Zinc $(\mathrm{mg} / \mathrm{kg})$ & 38.00 \\
\hline Copper (mg/kg) & 10.80 \\
\hline Selenium (mg/kg) & 0.38 \\
\hline $\begin{array}{l}{ }^{*} \text { Vitamin-mineral premix containe } \\
24.64 \% \mathrm{Na} ; 4.22 \% \mathrm{Cl} ; 16.42 \mathrm{mg} / \mathrm{k} \\
4,960 \mathrm{mg} / \mathrm{kg} \text { of } \mathrm{Fe} ; 122.64 \mathrm{mg} / \mathrm{kg} \text { of } \\
\mathrm{mg} / \mathrm{kg} \text { of } \mathrm{Se} ; 5,560 \mathrm{mg} / \mathrm{kg} \text { of } \mathrm{Zn} \text {; } \\
213,680 \mathrm{IU} / \mathrm{kg} \text { of vitamin } \mathrm{D} ; 4,480 \mathrm{I}\end{array}$ & $\begin{array}{l}17.70 \% \mathrm{Mg} ; 3.60 \% \mathrm{~K} \\
\text { of } \mathrm{Co} ; 1,642 \mathrm{mg} / \mathrm{kg} \text { of } \mathrm{Cu} \\
6,040 \mathrm{mg} / \mathrm{kg} \text { of } \mathrm{Mn} ; 45.37 \\
0,960 \mathrm{IU} / \mathrm{kg} \text { of vitamin } \mathrm{A} \\
\mathrm{kg} \text { of vitamin } \mathrm{E} \text {. }\end{array}$ \\
\hline
\end{tabular}

Feeding regimen and management: Animals were placed individually in concreted floor pens to collect feces and urine separately. Experimental animals were fed twice daily (09:00 and 16.00 h) at the rate of 90\% of voluntary intake of the adjustment period (Yunus et al., 2004). During the experiment all the animals were managed under uniform conditions. Ad libitum fresh and clean water was provided daily to the animals. Daily feed intake was recorded for each animal by subtracting orts from feed offered before the morning feeding. The cows were milked twice daily and milk production was recorded for each milking.

Before the start of the trial, the animals were treated with commercial anti-parasites medicine (Dectomax; Pfizer Animal Health) for controlling of internal and external parasites. All of the cows had been previously vaccinated against foot and mouth disease and hemorrhagic septicemia (manufactured by Veterinary Research Institute Lahore).

Sample collection and processing: Total orts were collected daily while samples of the TMR $(1 \mathrm{~kg})$ were collected on a weekly basis and then stored at $-20{ }^{\circ} \mathrm{C}$ for subsequent laboratory analysis. Following an acclimatization period of 21 days, feces and urine were collected for 5 days. Each day and at 4 hours intervals, feces were collected for individual animals, weighed, thoroughly mixed and a sub-sample ( $10 \%$ by weight) was taken and stored in plastic bags at $-20{ }^{\circ} \mathrm{C}$ for subsequent analysis of minerals content.

On day 20 of the adaptation period a sterile Foley urinary catheter was inserted into the urethra of 
each animal to enable collection of urine. The urinary catheter emptied into a collection vessel and at 4 hour interval, the amount of urine void was measured and acidified to $\mathrm{pH}$ lower than $2(22 \mathrm{~mL}$ of $6 \mathrm{~N} \mathrm{HCl} / \mathrm{L}$ of urine), sub-sampled ( $10 \%$ by volume) and stored at $-20 \mathrm{C}^{\circ}$ for further analysis. Milk samples (120 ml each) were collected at 10 consecutive milkings and stored at $-20^{\circ} \mathrm{C}$.

Laboratory analysis: The fecal samples from individual animals were thawed at room temperature and combined to make one composite sample per animal. The composite fecal samples and feed samples (orts and TMR) were dried to constant weight at $60^{\circ} \mathrm{C}$ in a hot air oven. For DM analysis a separate sample was dried at $100^{\circ} \mathrm{C}$ to constant weight. After drying, the samples were ground to pass a $1 \mathrm{~mm}$ screen (Willey mill; Arthur $\mathrm{H}$. Thomas Co., Philadelphia, PA).

Proximate composition of feed and orts samples was analyzed following standard procedures according to the Association of Official Analytical Chemists (AOAC, 2000). The acid detergent fiber (ADF) and neutral detergent fiber (NDF) contents were determined according to Van Soest et al. (1991). The gross energy of the TMR was determined using the bomb calorimetric method.

The feed, orts, feces, urine and milk samples were analyzed for P (AOAC, 2000), Ca, Mg (Atomic Absorption Spectrophotometer) and $\mathrm{Zn}$ (Inductively Coupled Plasma Optical Emission Spectrometry) concentrations (AOAC, 2000).

Calculations: Apparent digestibility was calculated as (mineral intake - mineral in faeces) / mineral intake) $\mathrm{x}$ 100. Apparent retention was calculated as (mineral intake - mineral in faeces - mineral in urine - mineral in milk) / mineral intake) x 100 .

Statistical analysis: The data thus collected on minerals intake, apparent digestibility and apparent retention were statistically analyzed using ANOVA (Steel et al., 1997). Means were compared for significance of difference using Duncan Multiple Range Test (Duncan, 1955). Differences were declared significant at $P<0.05$.

\section{RESULTS}

Dry matter digestibility: As shown in Table 1.3, there was no effect $(\mathrm{P}>0.05)$ of dietary treatment on apparent digestibility of DM.

Milk Yield: Dietary $\mathrm{Ca}$ and $\mathrm{P}$ levels and their ratios did not affect $(\mathrm{P}>0.05)$ daily milk yield (Table 1.3).

Intake, apparent digestibility and apparent retention of minerals

Calcium: Dietary $\mathrm{Ca}$ levels had a significant $(\mathrm{P}<0.05)$ effect on its apparent digestibility and retention (Table 1.3). Groups HC and HCHP had lower $(\mathrm{P}<0.05)$ apparent $\mathrm{Ca}$ digestibility than all other groups.

Groups LC and LCHP were in negative $\mathrm{Ca}$ balance as indicated by the negative values for apparent $\mathrm{Ca}$ retention (Table 1.3). All of the other groups were in positive $\mathrm{Ca}$ balance. There was no significant difference $(\mathrm{P}>0.05)$ in apparent $\mathrm{Ca}$ retention between those groups that were in positive $\mathrm{Ca}$ balance.

Phosphorus: Increased dietary $\mathrm{P}$ levels decreased $(\mathrm{P}<$ 0.05 ) apparent $\mathrm{P}$ digestibility irrespective of dietary $\mathrm{Ca}$ levels.

Magnesium: Increasing dietary $\mathrm{Ca}$ levels (Groups $\mathrm{HC}$ and HCP) decreased $(\mathrm{P}<0.05) \mathrm{Mg}$ apparent digestibility and apparent retention, with animals fed these diets being in negative $\mathrm{Mg}$ balance (Table 1.3). Animals fed the LC diet had the highest $(\mathrm{P}<0.05)$ apparent $\mathrm{Mg}$ digestibility. There was no significant difference $(\mathrm{P}>0.05)$ in apparent $\mathrm{Mg}$ retention between the groups in positive $\mathrm{Mg}$ balance.

Zinc: Increasing dietary Ca levels (Groups HC and HCP) decreased $(\mathrm{P}<0.05)$ both $\mathrm{Zn}$ apparent digestibility and apparent retention, with animals fed these diets being in negative $\mathrm{Zn}$ balance (Table 1.3). There was no significant difference $(P>0.05)$ in apparent $\mathrm{Zn}$ retention between those groups that were in positive $\mathrm{Zn}$ balance. 
Table 1.3. Average ( \pm SD) dry matter digestibility, and intake, apparent digestibility and apparent retention of calcium, phosphorus, magnesium and zinc in lactating Sahiwal cow fed different dietary levels of calcium and phosphorus.

\begin{tabular}{|c|c|c|c|c|c|c|c|}
\hline \multirow[t]{2}{*}{ Parameter } & \multicolumn{6}{|c|}{ Dietary treatment groups } & \multirow[t]{2}{*}{ Interactions } \\
\hline & NCP & HP & $\mathbf{L C}$ & LCHP & HC & НСНР & \\
\hline Dry matter digestibility (\%) & $65.3 \pm 0.72$ & $64.8 \pm 0.58$ & $65.51 \pm 0.87$ & $66.18 \pm 0.90$ & $64.92 \pm 0.65$ & $65.33 \pm 0.99$ & \\
\hline Milk yield (liters/day) & $6.22 \pm 0.16$ & $6.00 \pm 0.31$ & $6.1 \pm 0.34$ & $5.87 \pm 0.58$ & $6.3 \pm 0.36$ & $6.27 \pm 0.15$ & \\
\hline \multicolumn{8}{|l|}{ Calcium } \\
\hline Intake $(\mathrm{g} / \mathrm{d})$ & $42.3 \pm 0.87$ & $43.0 \pm 0.75$ & $25.8 \pm 0.33$ & $25.4 \pm 0.48$ & $61.3 \pm 1.25$ & $61.8 \pm 1.58$ & \\
\hline Apparent digestibility (\% of intake) & $25.1^{\mathrm{a}} \pm 0.91$ & $23.3^{\mathrm{a}} \pm 1.09$ & $23.4^{\mathrm{a}} \pm 1.20$ & $22.1^{\mathrm{a}} \pm 0.83$ & $17.9^{\mathrm{b}} \pm 0.76$ & $17.2^{\mathrm{b}} \pm 0.85$ & $\mathrm{Ca}, \mathrm{P} ; \mathrm{ns}$ \\
\hline Apparent retention ( $\%$ of intake) & $5.0^{\mathrm{c}} \pm 0.86$ & $4.2^{b c} \pm 1.52$ & $-1.9^{\mathrm{a}} \pm 0.51$ & $-2.2^{\mathrm{a}} \pm 1.11$ & $2.2^{\mathrm{bc}} \pm 0.57$ & $1.7^{\mathrm{b}} \pm 0.51$ & $\mathrm{Ca}, \mathrm{P} ; \mathrm{ns}$ \\
\hline \multicolumn{8}{|l|}{ Phosphorus } \\
\hline Intake (g/d) & $27.6 \pm 0.56$ & $39.0 \pm 0.68$ & $27.7 \pm 0.36$ & $38.2 \pm 0.72$ & $28.6 \pm 0.58$ & $40.2 \pm 1.02$ & $\mathrm{Ca}, \mathrm{P} ; \mathrm{ns}$ \\
\hline Apparent digestibility ( $\%$ of intake) & $35.3^{\mathrm{b}} \pm 0.41$ & $30.1^{\mathrm{a}} \pm 0.50$ & $34.5^{\mathrm{b}} \pm 0.47$ & $29.9^{\mathrm{a}} \pm 0.91$ & $35.7^{\mathrm{b}} \pm 0.53$ & $28.3^{\mathrm{a}} \pm 0.82$ & $\mathrm{Ca}, \mathrm{P} ; \mathrm{ns}$ \\
\hline Apparent retention ( $\%$ of intake) & $12.1 \pm 0.55$ & $10.7 \pm 0.92$ & $12.7 \pm 0.97$ & $10.5 \pm 1.12$ & $13.3 \pm 1.53$ & $9.8 \pm 1.03$ & $\mathrm{Ca}, \mathrm{P}, \mathrm{ns}$ \\
\hline \multicolumn{8}{|l|}{ Magnesium } \\
\hline Intake $(\mathrm{g} / \mathrm{d})$ & $21.7 \pm 0.44$ & $22.0 \pm 0.39$ & $21.8 \pm 0.28$ & $21.5 \pm 0.41$ & $22.5 \pm 0.46$ & $22.7 \pm 0.58$ & $\mathrm{Ca}, \mathrm{P} ; \mathrm{ns}$ \\
\hline Apparent digestibility (\% of intake) & $35.1^{\mathrm{bc}} \pm 0.73$ & $34.3^{b} \pm 0.75$ & $36.5^{\mathrm{bc}} \pm 0.95$ & $37.80^{c} \pm 1.08$ & $28.8^{\mathrm{a}} \pm 0.97$ & $28.1^{\mathrm{a}} \pm 0.74$ & $\mathrm{Ca}, \mathrm{P} ; \mathrm{ns}$ \\
\hline Apparent retention ( $\%$ of intake) & $8.5^{b c} \pm 1.20$ & $7.5^{\mathrm{b}} \pm 0.58$ & $11.5^{\mathrm{cd}} \pm 0.70$ & $13.4^{\mathrm{d}} \pm 1.26$ & $-3.1^{\mathrm{a}} \pm 1.29$ & $-4.8^{\mathrm{a}} \pm 1.33$ & $\mathrm{Ca}, \mathrm{P} ; \mathrm{ns}$ \\
\hline \multicolumn{8}{|l|}{ Zinc } \\
\hline Intake (mg/d) & $374.1 \pm 7.64$ & $379.9 \pm 6.65$ & $376.4 \pm 4.85$ & $371.8 \pm 7.02$ & $388.2 \pm 7.91$ & $391.2 \pm 9.99$ & \\
\hline Apparent digestibility ( $\%$ of intake) & $18.4^{\mathrm{b}} \pm 0.86$ & $18.8^{\mathrm{b}} \pm 1.22$ & $19.3^{\mathrm{b}} \pm 0.86$ & $20.2^{\mathrm{b}} \pm 0.85$ & $10.3^{\mathrm{a}} \pm 1.28$ & $10.3^{\mathrm{a}} \pm 1.05$ & $\mathrm{Ca}, \mathrm{P} ; \mathrm{ns}$ \\
\hline Apparent retention ( $\%$ of intake) & $3.8^{\mathrm{b}} \pm 0.75$ & $4.2^{\mathrm{b}} \pm 1.24$ & $5.0^{b} \pm 0.63$ & $5.2^{\mathrm{b}} \pm 1.26$ & $-4.9^{\mathrm{a}} \pm 1.53$ & $-5.4^{\mathrm{a}} \pm 1.07$ & $\mathrm{Ca}, \mathrm{P} ; \mathrm{ns}$ \\
\hline
\end{tabular}

Means in the same row followed by different superscript letters differed $(P<0.05)$. Ca, $\mathrm{P}=$ interaction between Ca and $\mathrm{P}$. ns $=$ non-significant at $P<0.05$. 


\section{DISCUSSION}

Dry matter digestibility: Dry matter digestibility did not differ between the experimental rations. The levels of dietary $\mathrm{Ca}$ and $\mathrm{P}$ as well as the ratio between these two minerals did not impact on DM digestibility (Table 1.3). Similar findings were reported by Moreiva et al (2009) by conducting trial on transition cows. These cows were offered high (0.64\%) and low (0.46\%) Ca levels in their rations along with high $(0.47 \%)$ and low $(0.38 \%) \mathrm{P}$ on DM basis. At all levels of Ca and P, DM intake remained unaffected. Similar results were obtained by Patino et al (2013) in their study involving lambs. Increasing P intake did not affect DM digestibility or OM digestibility, only mineral matter digestibility was negatively affected. Similarly, Begum et al. (2010) found no effect on DM digestibility with feeding $\mathrm{Ca}$ and $\mathrm{P}$ at 80,100 and $120 \%$ of the NRC recommendations to the Nili Ravi buffaloes.

Milk production: Neither $\mathrm{Ca}$ or $\mathrm{P}$ level nor the ratio impacted on milk yield. Puggaard et al. (2014) found that decreasing $\mathrm{P}$ levels below $0.23 \%$ reduced milk production in early lactation; whereas, decreasing dietary P from $0.34 \%$ to $0.28 \%$ did not impact either DMI or milk production during the whole lactation period. However, during their trial at week 12, treatment group fed $0.23 \%$ dietary $\mathrm{P}$ was shifted to the high $\mathrm{P}$ diet $(0.34 \%)$ because of high number of health issues. It was suggested that $\mathrm{P}$ mobilized from the bones was sufficient to meet the $\mathrm{P}$ requirements during mid and late lactation but not early lactation. Similar to the present study, Belyea et al (1976) found that feeding lower dietary Ca $(0.25 \%)$ for 8 weeks did not affect the milk production of Holstein cows. Wang et al (2014) offered $0.57 \%$ (high), $0.47 \%$ (medium) and $0.37 \%$ (NRC recommended) levels of $\mathrm{P}$ to multiparous Holstein cattle. Even for high yielding cows lowering P (0.57 to $0.37 \%)$ did not cause any reduction in milk yield but decreased $\mathrm{P}$ excretion, which is environmentally beneficial. Morse et al. (1992) observed no effect of different dietary P levels $(0.33,0.43$ and $0.54 \%$ ) and $\mathrm{Ca}$ : $\mathrm{P}$ ratios between $1.1: 1$ and $2.9: 1$ on $3.5 \%$ fat corrected milk yield in Holstein cows.

Partially in agreement with the present study, Begum et al, (2010) reported increased milk production at $120 \%$ NRC recommended $\mathrm{Ca}$ and $\mathrm{P}$ levels (as compared to $80 \%$ and $100 \%$ ) in Nili-Ravi buffaloes. No effect was observed between the groups fed $80 \%$ and $100 \%$ of NRC recommended levels. Individual effects of dietary $\mathrm{Ca}$ and $\mathrm{P}$ were not studied in their experiment. In contrast, Kincaid et al. (1981) observed increased milk production at higher $(0.55 \%$ vs $0.30 \%)$ dietary P levels. Similarly, Wu et al. (2001) offered diets containing three $\mathrm{P}$ levels $(0.31,0.39$ and $0.47 \%)$ on DM basis to multiparous Holstein cows and found that $0.31 \%$ appeared to be borderline deficient level for high yielding cows. This level was also less than NRC recommendations. Valk and Sebek (1999) reported a decrease in milk yield at lower dietary P levels $(0.24 \%$ vs $0.37 \%$ and $0.57 \%$ ) This difference in response could be attributed to the difference in daily milk yield as in the current study, animals used were low yielder (producing 5-6 L/d). Supplying dietary $\mathrm{Ca}$ and $\mathrm{P}$ at lower levels for a short-term period likely initiated the mobilization of these minerals from bones to meet the physiological needs.

Calcium and Phosphorus (Levels and ratios): Decline in $\mathrm{Ca}$ digestibility and retention were directly related to increasing levels of $\mathrm{Ca}$, irrespective of dietary $\mathrm{P}$ levels (Table 1.3). Our data support the original hypothesis of the study. The experimental diets had similar nutrient composition except with different $\mathrm{Ca}$ and $\mathrm{P}$ concentrations (Table 1.2). The Ca: $\mathrm{P}$ ratio varied (1: 1 to $1.4: 1.1)$ but remained within the critical limits $>7: 1$ or $<$ 1:1 (ARC, 1980; Miller 1983). This is in agreement with Taylor et al. (2009) who reported a linear effect of dietary Ca levels (high $1.03 \%$; medium $0.78 \%$; and low: $0.52 \%$ ) on fecal $\mathrm{Ca}$ excretion in lactating Holstein cows. More $\mathrm{Ca}$ was excreted by cows consuming more dietary $\mathrm{Ca}(195.40,151.6$ and $79.1 \mathrm{~g} / \mathrm{cow} / \mathrm{d}$ in high, medium and low dietary Ca groups, respectively). These findings also supported results of the present study that requirements of $\mathrm{P}$ in lactating cows are independent of dietary $\mathrm{Ca}$ concentrations. Verdaris and Evans (1976) evaluated effect of dietary $\mathrm{Ca}$ on minerals balance in Holstein cows and found that $\mathrm{Ca}$ digestibility and retention (percent of intake) were higher with low dietary Ca. Similarly, Graces and Evans (1971) reported depression in Ca absorption with high dietary levels in growing cattle.

With regards to Ca retention and digestibility it is not only the $\mathrm{Ca}$ concentration in diet that matters but also the Ca:P ratio. Moreira et al (2009) fed $0.64 \%(\mathrm{HCa})$ and $0.46 \%(\mathrm{LCa}) \mathrm{Ca}$ in their rations along with $0.47 \%$ (HP) and $0.38 \%$ (LP) P on DM basis. Results clearly indicated that $\mathrm{Ca}$ and $\mathrm{P}$ interaction impacted on $\mathrm{Ca}$ digestibility as well as apparent absorption. Higher dietary levels of $\mathrm{P}$ also negatively affect the absorption of Ca (Tanaka and DeLuca, 1973). Similar results were found by Neil et al. (2015) who conducted trial on beef cattle. They reported if forage $\mathrm{P}$ content supply was ample for grazing cattle, increasing $\mathrm{P}$ supplementation could result in more $\mathrm{P}$ excretion without additional benefits to growth or nutrient digestibility. Greater excretion of $\mathrm{P}$ can have negative environmental impacts. This not only causes accelerated growth of algae or other aquatic plants but nutrient management issue forcing producers to overcome increased $\mathrm{P}$ excretion rate. Increasing the level of dietary $\mathrm{P}$, decreased $\mathrm{P}$ digestibility in the present study, irrespective of the dietary Ca levels and Ca: $\mathrm{P}$ ratios. Reduction in $\mathrm{P}$ absorption at high $\mathrm{P}$ intake is usual (Guyton et al., 2003).

The small intestine is the major site for $\mathrm{Ca}$ absorption (Schröder and Breves, 2006); however, higher 
$\mathrm{Ca}$ concentrations in the rumen result in considerable absorption of Ca prior to the abomasum (Khorasani et al., 1997; Schröder and Breves, 2006). Small intestine, especially the duodenum and jejunum are considered as major sites for P absorption (Care, 1994; Khorasani et al., 1997); however, small amounts of $P$ are also absorbed from the rumen, omasum and abomasum.

Along with vitamin D $\left(1,25-(\mathrm{OH})_{2}\right.$ vitamin $\left.\mathrm{D}\right)$, parathyroid hormones (PTH) and calcitonin perform major roles in Ca homeostasis (Tsujikawa et al., 2003; Goff, 2006). Under circumstances of lower intake (than requirements), $\mathrm{Ca}$ deposited in bones and soft tissues returns to the extracellular pool to maintain normal $\mathrm{Ca}$ levels (Littledike and Goff, 1987). In the current study, the short term feeding of lower Ca levels (0.26\%) might have activated the same homeostatic mechanism to fulfill the physiological needs of the cows. Phosphorus absorption is affected by multiple factors including total $\mathrm{P}$ intake, source of $\mathrm{P}$, the $\mathrm{Ca}$ : $\mathrm{P}$ ratio, and dietary $\mathrm{Ca}, \mathrm{Mg}$ and fat levels (Ekelund, et al., 2003). Phosphorus absorption occurs via active and passive pathways. Vitamin D operates the active absorption when feed is low in $\mathrm{P}$, whereas, passive absorption is takes control when higher amounts of $P$ are fed (NRC, 2001).

Unlike non-ruminants, $\mathrm{P}$ homeostasis in ruminants is maintained through salivary recycling and endogenous fecal excretion (Karn, 2001; NRC, 2001). There is an inverse relation between amount of $\mathrm{P}$ fed and its absorption (Braithwaite, 1983; Klop et al., 2013). Schneider et al. (1985) found that when animals were offered $\mathrm{P}$ deficient diets, high levels of $\mathrm{Ca}$ reduced the absorption of $\mathrm{P}$, due to reduction in rumen $\mathrm{P}$ solubility and also due to less $\mathrm{P}$ availability in the lower GIT. Taylor et al. (2009) determined the effect of dietary Ca on minerals balance in lactating cows. Similar to the findings of the present study, no effect of dietary $\mathrm{Ca}$ levels (High: $1.03 \%$, Medium $0.78 \%$ and Low: $0.52 \%$ ) on $\mathrm{P}$ balance as found in lactating Holstein cows at 140 DIM. It was concluded that $\mathrm{P}$ requirements of lactating cows could be considered independent of dietary $\mathrm{Ca}$ levels. It was further described that this difference might be due to the fact that within experiments, DMI and milk yields were similar among treatments, whereas, in their data set, $\mathrm{P}$ intake was different in different experiments due to variation in DMI. Ruminants can tolerate a wide range of ratios of both the minerals but depends upon adequacy in supply of $\mathrm{Ca}$ and $\mathrm{P}$ along vitamin $\mathrm{D}$. When low $\mathrm{P}$ is fed to the ruminants, its homeostasis is maintained by reducing salivary $\mathrm{P}$ flow and increased absorption from small intestine (Coates and Ternouth, 1992).

Wang et al. (2014) studied effect of different levels of dietary $\mathrm{P}$ on its excretion in multiparous Holstein cows and found that decreasing dietary $\mathrm{P}$ from $0.57 \%$ to $0.37 \%$, significantly $(\mathrm{P}<0.05)$ reduced its urinary and faecal excretion. A decrease in apparent digestibility of $\mathrm{P}$ with increase in dietary $\mathrm{P}$ has been reported in various studies (Morse et al., 1992; Wu et al., 2000 and Knowlton and Herbein, 2002) in dairy cows. In contrast, Feng et al. (2015) reported lowest P digestibility in steers fed $0.15 \%$ dietary P. Similarly, Geisert et al. (2010) reported very low $\mathrm{P}$ digestibility in steers fed with $0.12 \%$ dietary P. Ternouth (1990) explained that slight reduction of $\mathrm{P}$ digestibility at very low dietary $\mathrm{P}$ levels can be attributed to the compromised microbial $P$ requirements. In the current study the lowest dietary $\mathrm{P}$ level was $0.28 \%$ which is much higher than the levels used in these studies. At this dietary level, microbial $\mathrm{P}$ requirements might be fulfilled.

Field et al. (1983) studied the effect of dietary $\mathrm{Ca}$ and $\mathrm{P}$ on $\mathrm{P}$ metabolism in sheep and reported reduction in $\mathrm{P}$ absorption with higher dietary $\mathrm{Ca}$ concentrations. Similarly, Verdaris and Evans (1976) reported that absorption and retention of $\mathrm{P}$ (percent of intake) was higher with low dietary $\mathrm{Ca}$ and lower with high dietary $\mathrm{Ca}(0.2$ vs $2.1 \%$ dietary $\mathrm{Ca})$. These findings are also contradictory to the findings of the present study. This difference may be attributed to the reason that variation in dietary $\mathrm{Ca}(0.26 \%, 0.43 \%$ and $0.60 \%$ of $\mathrm{DM})$ and $\mathrm{P}(0.28 \%$ and $0.39 \%$ of $\mathrm{DM})$ levels in the present study were higher than those used in these studies. Other factors like difference in nature of sample, physiological stage, breed, feeding pattern and experimental conditions can also impact on absorption and retention of these minerals.

Magnesium: Increasing dietary $\mathrm{Ca}$ levels ( $\mathrm{HC}$ and $\mathrm{HCHP})$ decreased $(\mathrm{P}<0.05)$ apparent digestibility of $\mathrm{Mg}$ in the lactating cows. These findings support the hypothesis. It was postulated that increasing dietary $\mathrm{Ca}$ would impact the $\mathrm{Mg}$ absorption; however, data on absorption of inorganic component of diet and their availability are inconsistent (Khorasani and Armstrong, 1992). Magnesium metabolism can be influenced by alterations in $\mathrm{Ca}$ and $\mathrm{P}$ levels in the diet (Littledike and Goff, 1987). Magnesium absorption is not dependent upon the requirements of the cow. Under normal circumstances, normal levels are maintained in the body by regulating its excretion through urine. There are no labile reserves of $\mathrm{Mg}$ within the body; dietary $\mathrm{Mg}$ appears to be only significant once $\mathrm{Mg}$ enters the extracellular pool (Ram et al., 1998). While considering the interrelationship of $\mathrm{Ca}, \mathrm{P}$ and $\mathrm{Mg}$, it is fundamental to note that a very high concentration of these minerals is ossified in bones and at the time of need, these can be mobilized (Khorasani et al., 1997). The major site for $\mathrm{Mg}$ absorption in adult animals is the rumen (Martens and Schweigel, 2000) where it is taken up by both potentialdependent and potential-independent mechanisms (Martens, 2018). Calcium and Mg competes with one another for the same binding sites. Kronqvist (2011) found that for non-lactating cows during the dry period, 
increased dietary levels of $\mathrm{Ca}(13.6 \mathrm{~g} / \mathrm{kg})$ decreased digestibility of $\mathrm{Mg}$ compared to lower dietary Ca levels (4.9 and $9.3 \mathrm{~g} / \mathrm{kg}$ ). Care (1994) also reported that higher dietary $\mathrm{Ca}$ levels decreased $\mathrm{Mg}$ absorption in cows. Lower bioavailability of $\mathrm{Mg}$ in response to higher dietary Ca levels was also reported by Alfaro et al. (1987). Verdaris and Evans (1976) reported Mg absorption and retention (percent of intake) was higher in Holstein cows fed on diets low in $\mathrm{Ca}(0.2 \%$ vs $2.1 \%)$. In contrast, Weiss and Wyatt (2004) reported no effect of dietary $\mathrm{Ca}$ and $\mathrm{P}$ levels on $\mathrm{Mg}$ digestibility. Results of Chicco et al. (1973) are also in line with the present study. They investigated the nutritional interrelationships of dietary $\mathrm{Ca}, \mathrm{P}$ and $\mathrm{Mg}$ in sheep and found very little effect of $\mathrm{P}$ but significant effect of high dietary $\mathrm{Ca}(0.78 \%)$ in reducing $\mathrm{Mg}$ in bone and blood plasma. Calcium and $\mathrm{Mg}$ have been considered as absorption inhibiters of each other (EFSA, 2006). Increased dietary levels of $\mathrm{Ca}$ and $\mathrm{P}$ also decrease $\mathrm{Mg}$ absorption by the formation of insoluble Ca-Mg-P complexes in the intestines (Brink et al., 1992). There is no hormonal system that directly regulates Mg absorption (Charlton and Armstrong, 1989; Urdaz et al., 2003). Circulating levels of PTH, 1, 25 $(\mathrm{OH})_{2} \mathrm{D}$ and calcitonin are determined by plasma $\mathrm{Ca}$ concentrations. Magnesium concentration is affected by these hormones secondarily (Reinhard et al., 1988). Along with the rumen $\mathrm{pH}$, dietary $\mathrm{Mg}$ level, solubility level of $\mathrm{Mg}$ in the rumen, dietary $\mathrm{K}$ (Weiss and Wyatt, 2004) and $\mathrm{Ca}$ (Schonewille et al., 1997) affect $\mathrm{Mg}$ absorption.

Zinc: Different chelating materials like phytate can affect $\mathrm{Zn}$ absorption particularly in monogastric animals but in most instances, the factors that disturb $\mathrm{Zn}$ requirements of large animals are not clear (Blackmon et al, 1967). Mostly, Zn deficiency for ruminants can be noticed under field conditions if forage $\mathrm{Zn}$ contents range from 19-83 ppm (Miller, 1970). In the present study, treatments with higher dietary $\mathrm{Ca}$ significantly $(\mathrm{P}<0.05)$ decreased $\mathrm{Zn}$ apparent digestibility. Feeding excessive quantities of $\mathrm{Ca}$ may decrease absorption of $\mathrm{Zn}$ in dairy cows (NRC, 2001). In studies with sheep, Suttle and Field (1970) found increased $(\mathrm{P}<0.5) \mathrm{Zn}$ excretion when dietary $\mathrm{Ca}$ was increased from 1.0 to $2.0 \%$. Perry et al. (1968) reported similar observations that by doubling the dietary $\mathrm{Ca}$ of beef cattle, hair $\mathrm{Zn}$ content was significantly $(\mathrm{P}<$ $0.5)$ decreased. Pond and Wallace (1986) also observed that plasma $\mathrm{Zn}$ of ewes fed with high $\mathrm{Ca}$ diet was decreased significantly $(\mathrm{P}<0.5)$. Higher levels of dietary $\mathrm{Ca}$ in the presence of dietary phytic acid source may decrease $\mathrm{Zn}$ absorption in monogastric animals (O'Dell et al., 1958). Kincaid (1979) found that unless fed with high dietary $\mathrm{Ca}(0.43$ and $0.6 \%)$, apparent digestibility of $\mathrm{Zn}$ remained between $18-20 \%$. Similar observations (12$22 \%$ ) have been reported in adult cattle in previous studies (Miller and Cragle, 1965; Hansard et al., 1968).
Available data suggests that there may be unknown organic factors present in common feedstuffs which can interfere with the absorption of zinc in ruminants and other species (NRC 2001).

In the present study dietary levels of $\mathrm{P}$ did not affect apparent $\mathrm{Zn}$ digestibility. These findings are contrary to our hypothesis. Similar results were found by Laflamme et al. (1985) who studied the effect of low and normal dietary $\mathrm{P}$ concentrations on $\mathrm{Zn}$ metabolism in calves. Neathery et al. (1990) reported increased apparent digestibility of $\mathrm{Zn}$ in Holstein calves fed with lower $\mathrm{P}$ levels. The interaction mechanism between dietary $\mathrm{Zn}$ and $\mathrm{P}$ to relative $\mathrm{Zn}$ absorption is not clearly understood. Miller (1981) described that in cows $\mathrm{Zn}$ absorption may increase as a consequence of active homeostatic means with low $\mathrm{P}$ diets. It was further reported little effect of dietary $\mathrm{Ca}$ on $\mathrm{Zn}$ digestibility. Plasma $\mathrm{Zn}$ concentration is the most widely used indicator for $\mathrm{Zn}$ status in animals. When plasma $\mathrm{Zn}$ concentration drastically reduces (within 24 to $36 \mathrm{~h}$ ), it causes a decline in feed intake (Spais and Papasteriadis, 1974); however, in present study, feed intake remained unaffected and $\mathrm{Zn}$ levels remained at the required level and no $\mathrm{Zn}$ deficiency was noticed. In animals, Zn deficiency may be manifested in alteration in taste perception, accompanied by damage to the tongue epithelium (Anke et al., 1994) but no such effects were noticed in present study.

\section{REFERENCES}

Alfaro, E., M. Neathery, W. Miller, R. Gentry, C. Crowe, A. Fielding, R. Etheridge, D. Pugh and D. Blackmon (1987). Effects of varying the amounts of dietary calcium on selenium metabolism in dairy calves. J Dairy Sci. 70(4): 831-836.

Anke, M., B. Groppel and L. Angelow (1994). The influence of manganese, zinc, copper, iodine and selenium deficiency on reproductive ability of ruminants. Rek J. 1: 23-28.

AOAC (2000). Official methods of analysis. Arligton, Virginia, USA: Association of Analytical Chemists. 17.

Begum, I., A. Azim, S. Akhter, M.I. Anjum and M. Afzal (2010). Mineral dynamics of blood and milk in dairy buffaloes fed on calcium and phosphorus supplementation. Pak Vet J. 30: 105-109.

Belyea, R.L., C.E. Coppock and G.B. Lake (1976). Effects of a low calcium diet on feed intake, milk production, and response to blood calcium challenge in lactating Holstein cows. J Dairy Sci. 59: 1068-1077.

Blackmon, D.M., W.J. Miller and J.D. Morton (1967). Zinc deficiency in ruminants. Vet Med. 62: 265. 
Braithwaite, G.D. (1983). Calcium and phosphorus requirements of the ewe during pregnancy and lactation. Br J Nutr. 50(3): 723-736.

Brink, E.J., A.C. Beynen, P.R. Dekker, E.C. van Beresteijn and R. van der Meer (1992). Interaction of calcium and phosphate decreases ileal magnesium solubility and apparent magnesium absorption in rats. J Nutr. 122(3): 580-6.

Care, A. (1994). The absorption of phosphate from the digestive tract of ruminant animals. British Vet J. 150(2): 197-205.

Chapuis-Lardy, L., J. Fiorini, J. Toth and Z. Dou (2004). Phosphorus concentration and solubility in dairy feces: Variability and affecting factors. J Dairy Sci. 87(12): 4334-4341.

Charlton, J.A. and D.G. Armstrong (1989). The effect of intravenous infusion of aldosterone upon magnesium metabolism in the sheep. Q J Exp Physiol. 74: 329-37.

Chicco, C.F., C. B. Ammerman and P.E. Loggins (1973). Effect of age and dietary magnesium on voluntary feed intake and plasma magnesium in ruminants. J Dairy Sci. 56: 822-824.

Coates, D.B. and J.H. Ternouth (1992). Phosphorus kinetics of cattle grazing tropical pastures and implications for the estimation of their phosphorus requirements. J Agric Sci. 119: 401409.

Duncan, D.B. (1955). Multiple range and multiple F tests. Biometrics. 11(1): 1-42.

EFSA. (2006). European Food Safety Authority. Tolerable upper intake levels for vitamins and minerals. http://www.efsa.eu.int

Ekelund, A., R. Spörndly, H. Valk and M. Murphy (2003). Influence of feeding various phosphorus sources on apparent digestibility of phosphorus in dairy cows. Anim Feed Sci Technol. 109: 95104.

Feng, X., E. Ronk, M.D. Hanigan, K.F. Knowlton, H. Schramm and M. McCann (2015). Effect of dietary phosphorus on intestinal phosphorus absorption in growing Holstein steers. J Dairy Sci. 98: 3410-3416.

Field, A., J. Kamphues and J. Woolliams (1983). The effect of dietary intake of calcium and phosphorus on the absorption and excretion of phosphorus in chimaera-derived sheep. J Agric Sci. 101(03): 597-602.

Garces, M. A., and J. L. Evans (1971). Calcium and magnesium absorption in growing cattle as influenced by age of animal and source of dietary nitrogen. J. Anim. Sci. 32:789.

Geisert, B.G., G.E. Erickson, T.J. Klopfenstien, C.N. Macken, M.K. Lubbe and J.C. MacDonald (2010). Phosphorus requirement and excretion of finishing beef cattle fed different concentrations of phosphorus. J Anim Sci. 88:2393-2402.

Goff, J. (2006). Macromineral physiology and application to the feeding of the dairy cow for prevention of milk fever and other periparturient mineral disorders. Anim Feed Sci Technol. 126: 237257.

Guyton, A.D., J.M. McKinney and K.F. Knowlton (2003). The effect of steam-flaked or dry ground corn and supplemental phytic acid on phosphorus partitioning and ruminal phytase activity of lactating dairy cows. J Dairy Sci. 86: 3972-3982.

Hansard, S.L., A.S. Mohammed and J.W. Turner JW (1968). Gestation age effects upon maternalfetal zinc utilization in the bovine. J Anim Sci. 27: 1097-1102.

Harris Jr, B., A.L. Adams and H.H. Van Horn (2003). Mineral needs of dairy cattle. Circular-Florida cooperative extension service (USA). 1-17.

Harrison J.H. and H.R. Conrad (1984). Effect of dietary calcium on selenium absorption by the nonlactating dairy cows. J Dairy Sci. 67(8): 1860-1864.

Horst, R.L. (1986). Regulation of calcium and phosphorus homeostasis in the dairy cow. J Dairy Sci. 69(2): 604-616.

Karn, J.F. (2001). Phosphorus nutrition of grazing cattle: A review. Anim Feed Sci Technol. 89:133-135.

Khorasani, G., R. Janzen,W. McGill W and J. Kennelly (1997). Site and extent of mineral absorption in lactating cows fed whole-crop cereal grain silage of alfalfa silage. J Anim Sci. 75(1): 239-248.

Khorasani, G.R. and D.G. Armstrong (1992). Calcium, phosphorus and magnesium absorption and secretion in the bovine digestive tract as influenced by dietary concentration of these elements. Livest. Prod. Sci. 31:271-286.

Kincaid, L.R., J.K. Hillers and J.D. Cronrath (1981). Calcium and phosphorus supplementation of rations for lactating dairy cows. J Dairy Sci. 64:754-758.

Kincaid, R.L. (1979). Biological availability of zinc from inorganic sources with excess dietary calcium. J Dairy Sci. 62: 1081-1085.

Klop, G., J.L. Ellis and A. Bannink (2013). Meta-analysis of factors that affect the utilization efficiency of phosphorus in lactating dairy cows. J Dairy Sci. 96: 3936-3949.

Knowlton, K., C. Parsons, C. Cobb and K. Wilson (2005). Exogenous phytase plus cellulase and phosphorus excretion in lactating dairy cows. PAS. 21(3): 212-216. 
Knowlton, K., J. Herbein (2002). Phosphorus partitioning during early lactation in dairy cows fed diets varying in phosphorus content. J Dairy Sci. 85(5): 1227-1236.

Kronqvist, C. (2011). Minerals to dairy cows with focus on calcium and magnesium balance. PhD. thesis. Department of animal nutrition and management, Swedish University of Agricultural Sciences, Uppsala. p. 11-47.

Laflamme, D., W. Miller, M. Neathery, R. Gentry, D. Blackmon, K. Logner and A. Fielding (1985). The effect of low to normal dietary phosphorus levels on zinc metabolism and tissue distribution in calves. J Anim Sci. 61(2): 525-531.

Littledike, E.T. and J. Goff (1987). Interactions of calcium, phosphorus, magnesium and vitamin D that influence their status in domestic meat animals. J Anim Sci. 65(6): 1727-1743.

Martens, H. and M. Schweigel (2000). Pathophysiology of grass tetany and others hypomagnesaemias. Vet Clin North America. Food Animal Practice 16: 339-368.

Martens, H., S. Leonhard-Marek, M. Röntgen and F. Stumpff (2018). Magnesium homeostasis in cattle: absorption and excretion. Nutr Res Rev. 31(1): 114-130.

Martz, F., A. Belo, M. Weiss and R. Belyea (1999). True absorption of calcium and phosphorus from corn silage fed to nonlactating, pregnant dairy cows. J Dairy Sci. 82(3): 618-622.

McDowell, L,R. (1992). Minerals in animal and human nutrition. Academic Press Inc, San Diego, California, USA.

McDowell, L.R. (2003). Minerals in animal and human nutrition. Elsevier Science BV. p. 33-100.

McDowell, L.R. and J.D. Arthington (2005). Minerals for grazing ruminants in tropical regions. 5th ed. University of Florida, Gainesville, Fl. p. 83-95.

Miller, J.K. and R.G. Cragle (1965). Gastrointestinal sites of absorption and endogenous secretion of zinc in dairy cattle. J. Dairy Sci. 48: 370-373.

Miller, W. (1981). Mineral and vitamin nutrition of dairy cattle. J Dairy Sci. 64(6): 1196-1206.

Miller, W.J. (1970). Zinc nutrition of cattle: a review. J Dairy Sci. 53: 1123-1135.

Miller, W.J. (1983). Using mineral requirement standards in cattle feeding programs and feed formulations. Georgia Nutrition Conference for the Feed Industry, University of Georgia, Athens. pp. 69-74.

Moreira, V.R., L.K. Zerinue and C.C. Williams (2009). Influence of calcium and phosphorus feeding on markers of boné metabolism in transition cows. J Dairy Sci. 92: 5189-5198.

Morse, D., H. Head, C. Wilcox, H. Van Horn, C. Hissem and B. Harris B. (1992). Effects of concentration of dietary phosphorus on amount and route of excretion. J Dairy Sci. 75(11): 3039-3049.

Neathery, M., N. Crowe, W. Miller, C. Crowe, J. Varnadoe and D. Blackmon (1990). Influence of dietary aluminum and phosphorus on zinc metabolism in dairy calves. J Anim Sci. 68(12): 4326-4333.

Neil, S.J. (2015). Effects of phosphorus supplementation on grazing beef cattle. MSc thesis. Faculty of Virginia Polytechnic Institute and State University.

NRC (1980). The nutrient requirements of ruminant livestock. Agricultural Research Council Technical review, Famham Royal U.K. Commonwealth Agricultural Research Bureau, England.

NRC. (1989). Nutrient requirements of dairy cattle. National Research Council. 6th ed, National Academy of Sciences, Washington, DC, USA.

NRC. (2001). Nutrient requirements of dairy cattle. National Research Council. 7th ed. National Academy of Sciences, Washington, DC, USA.

Oberleas, D. and B. Harland (1996). Impact of phytic acid on nutrient availability. Phytase in animal nutrition and waste management. pp. 77-84.

O'Dell, B.L., P.M. Newberne and J.E. Savage (1958). Significance of dietary zinc for the growing chicken. J. Nutr. 65: 503-523.

Patiño, P.R., T. Da Silva, J.C. Silva Filho, E. Nasser, D.M. Vitti and A. Moreira (2013). Nutrient absorption in lambs fed diets containing different amounts of phosphorus. Rev. MVZ Córdoba. 18(2):3444-3451.

Perry, T.W., W.M. Beeson, W.H. Smith and M.T. Mohler (1968). Value of zinc supplementation of natural rations for fattening beef cattle. J Anim Sci. 27(6): 1674-1677.

Pond, W. and M. Wallace (1986). Effect of gestationlactation diet calcium and zinc levels and of parenteral vitamins $\mathrm{A}, \mathrm{D}$ and $\mathrm{E}$ during gestation on ewe body weight and on lamb weight and survival. J Anim Sci. 63(4): 1019-1025.

Puggaard, L., P. Lund, A. Liesegang and J. Sehested (2014). Long term effect of reduced dietary phosphorus on feed intake and milk yield in dry and lactating dairy cows. Livest Sci. 159:18-28.

Ram, L. J.T. Schonewille, H. Martens, A.T. Van't Klooster and A.C. Beynen (1998). Magnesium absorption by wethers fed potassium bicarbonate in combination with different dietary magnesium concentrations. J Dairy Sci. 81:2485-2492.

Reinhardt, T.A., L.H. Ronald and J. Goff (1988). Phosphorus and magnesium homeostasis in 
ruminants. Vet Clinics of North America. Food Animal Practice. 4: 331-50.

Schneider, K.M., J.H. Ternouth, C.C. Sevilla and R.C. Boston (1985). A short-term study of calcium and phosphorus absorption in sheep fed on diets high and low in calcium and phosphorus. Crop Pasture Sci. 36(1): 91-105.

Schonewille, J.T., L. Ram, A.T. Van'tKlooster, H. Wouterse and A.C. Beynen (1997). Intrinsic potassium in grass silage and magnesium absorption in dry cows. Livest Prod Sci. 48: 99110.

Schroder, B. and G. Breves (2006). Mechanisms and regulation of calcium absorption from the gastrointestinal tract in pigs and ruminants: comparative aspects with special emphasis on hypocalcemia in dairy cows. Anim Health Res Rev. 7: 31-41.

Spais, A.G. and A.A. Papasteriadis (1974). Zinc deficiency in cattle under Greek conditions. In: Trace element metabolism in animals-2. Baltimore: University Park Press: 628-31.

Steel, R.G.D., J.H. Torrie and D.A. Dickey (1997). Principles and procedures of statistics: A biometrial approach. 3rd ed. New York, USA: McGraw Hill Book Co. Inc. p. 481.

Suttle, N. and A. Field (1970). Effects of dietary calcium and phosphorus concentrations on faecal excretion of copper, manganese and zinc in sheep. In: Proceedings of the Nutrition Society, 29(2):33.

Tamminga, S. (1992). Nutrition management of dairy cows as a contribution to pollution control. J Dairy Sci. 75: 345.

Tanaka, Y. and H.F. Deluca (1973). The control of 25hydroxyvitamin D metabolism by inorganic phosphorus. Arch Biochem Biophys. 154: 566574.

Taylor, M., K. Knowlton, M. McGilliard, W. Swecker, J. Ferguson, Z. Wu and M. Hanigan (2009). Dietary calcium has little effect on mineral balance and bone mineral metabolism through twenty weeks of lactation in Holstein cows. J Dairy Sci. 92(1): 223-237.

Ternouth, J.H. (1990). Phosphorus and beef production in northern Australia. 3. Phosphorus in cattle-a review. Trop Grasslands. 24:159-169.

Tsujikawa, H., Y. Kurotaki, T. Fujimori, K. Fukudaa and Y. Nabeshima (2003). Klotho, a gene related to a syndrome resembling human premature aging, functions in a negative regulatory circuit of vitamin D endocrine system. Mol Endocrinol. 17(12): 2393-2403.

Underwood, E.J. and N.F. Suttle (1999). The Mineral Nutrition of Livestock. CABI Publishing. p. $67-$ 148.

Urdaz, J., J.E. Santos, P. Jardon and M.W. Overton (2003). Importance of appropriate amounts of magnesium in rations for dairy cows. $\mathrm{J}$ Am Vet Med Assoc. 222(11): 1518-23.

Valk, H., and L. B. J. Sebek (1999). Influence of prolonged feeding of limited amounts of phosphorus on dry matter intake, milk production, reproduction and body weight of dairy cows. J. Dairy Sci. 82:2157-2163.

Van Soest, Pv., J. Robertson and B. Lewis B. 1991. Methods for dietary fiber, neutral detergent fiber, and nonstarch polysaccharides in relation to animal nutrition. J Dairy Sci. 74(10): 35833597.

Verdaris, J.N. and J.L. Evans (1976). Diet calcium and $\mathrm{pH}$ versus mineral balance in Holstein cows 84 days pre-to 2 days postpartum. J Dairy Sci. 59(7): 1271-1277.

Wang, L.,Y. Lin, Y. Bian, L. Liu, L. Shao and L. Lin (2014). Leucyl-tRNAsynthetase regulates lactation and cell proliferation via mTOR signaling in dairy cow mammary epithelial cells. J Mol Sci. 15(4): 5952-5969.

Weiss, W. and D. Wyatt (2004). Macromineral digestion by lactating dairy cows: Estimating phosphorus excretion via manure. J Dairy Sci. 87(7): 2158 2166.

Wu, Z., A. Satter, J. Blohowiak, R. H. Stauffacher and J.H. Wilson (2001). Milk production, estimated phosphorus excretion, and bone characteristics of dairy cows fed different amounts of phosphorus for two or three years. J Dairy Sci. 84:1738-1748.

Wu, Z., L. Satter and R. Sojo (2000). Milk production, reproductive performance, and fecal excretion of phosphorus by dairy cows fed three amounts of phosphorus. J Dairy Sci. 83(5): 1028-1041.

Yunus, A. W., A. G. Khan, Z. Alam, J. I. Sultan and M. Riaz (2004). Effects of substituting cottonseed meal with sunflower meal in rations for growing buffalo calves. Asian Australasian J Anim Sci. 17(5): 659-662. 